\title{
FISH in Burkitt lymphoma diagnosis: a single Romanian center experience
}

\section{Tehnica FISH în diagnosticul limfomului Burkitt: experiența unui centru din România}

\author{
Ariana Neicu*, Maria Neagu, Maria Dobre, Roxana Ivan, Camelia Dobrea \\ "Victor Babes" National Institute, Bucharest, Romania
}

\begin{abstract}
The goal of this study, part of the PERSOTHER project, is the implementation a new ancillary technique - fluorescent in situ hybridization (FISH) - in Burkitt lymphoma (BL) diagnosis, for the first time in our country. BL is a B-cell lymphoma with a highly aggressive clinical course. Three clinical variants of BL are recognized: endemic BL (in equatorial Africa), sporadic (throughout the world) and immunodeficiency-associated BL. The 2008 World Health Organization (WHO) Classification described a new category of B-cell lymphoma, unclassifiable, with intermediate features between diffuse large B-cell lymphoma (DLBCL) and BL. Because the treatment of $B L$ is very aggressive, with high doses chemotherapy, an accurate diagnosis is required. Cytology, morphology and immunophenotype (CD20+, CD10+, BCL6+, BCL2-, Ki67 98-100\%) are typical for BL. Most of the cases have MYC translocation at band $8 q 24$ to the IgH region, 14q32. The demonstration of MYC translocation is necessary for BL diagnosis and differential with DLBCL and borderline cases. 22 cases of BL were evaluated by FISH for MYC translocation. 17 cases were positive, one case was negative and 4 cases were inconclusive. The results are concordant with the literature: the authors report about 10\% MYC negative cases. In this cases micro-RNA (MiRNA-s) alterations may be implicated. The present study highlights the importance of FISH in BL diagnosis. It also identifies some of the technical difficulties of this method and it represents a basis for future routine diagnosis of selected $B L$ cases.
\end{abstract}

Keywords: Burkitt lymphoma, FISH, MYC rearrangement

\section{Rezumat}

Scopul acestui studiu, parte a proiectului PERSOTHER, este implementarea unei tehnici noi - hibridizarea in situ cu imunofluorescența (FISH) - in diagnosticul limfoamelor Burkitt (BL), pentru prima dată în țara noastră. BL este un limfom cu celulă B de mare agresivitate clinică. Sunt recunoscute 3 variante de LB: endemică (în Africa ecuatorială), sporadică (peste tot in lume) şi asociată cu imunodeficiența. Clasificarea Organizației Mondiale a Sănătății din 2008 a descris o nouă formă de limfom cu celulă B, neclasificabil, cu caractere intermediare intre un limfom difuz cu celulă mare B şi un BL. Deoarece tratamentul BL este foarte agresiv, cu chimioterapie in doze mari, un diagnostic corect este obligatoriu. Citologia, morfologia şi imunofenotipul

${ }^{*}$ Corresponding author: Ariana Neicu, Str. Zamfirei, Nr 30, Mogosoaia, Jud. Ilfov

Phone: 0723626223, E-mail: stefania.ariana.visan@gmail.com 
(CD20+, CD10+, BCL6+, BCL2-, Ki67 98-100\%) sunt tipice pentru BL. Majoritatea au o translocație a genei MYC, localizate pe $8 q 24$ cu gena pentru IgH, 14q32. Demonstrarea transocației MYC este necesară pentru diagnosticul de BL şi pentru diferențierea de un DLBCL, în unele cazuri. 22 de cazuri de BL au fost evaluate prin FISH pentru translocația MYC. 17 cazuri au fost pozitive, un caz a fost negativ şi 4 cazuri au fost neconcludente. Aceste rezultate sunt concordante cu literatura de specialitate: autorii raportează aproximativ $10 \%$ cazuri de BL fără transocație MYC. În aceste cazuri pot fi implicate alterări ale micro-ARN. Studiul actual evidențiază importanța FISH in diagnosticul BL, identifică unele dificultăți tehnice ale metodei şi reprezintă pentru viitor, o bază a diagnosticului de rutină, în cazuri selecționate.

Cuvinte cheie: Limfom Burkitt, FISH, rearanjare MYC

Received: $9^{\text {th }}$ July 2013; Accepted: $30^{\text {th }}$ October 2013; Published: $13^{\text {th }}$ November 2013.

\section{Introduction}

The main purpose of the PERSOTHER project was the implementation of molecular biology techniques in routine diagnostic practice. The goal of this study, part of the PERSOTHER project, is the implementation a new ancillary technique - FISH - in BL diagnosis, for the first time in our country. Burkitt lymphoma (BL) in an aggressive B-cell neoplasm of germinal center origin. Most of Burkitt lymphoma cases are associated with Epstein-Barr Virus (EBV) infection. The incidence of EBV infection varies between $30 \%$ in the developed world and $70-80 \%$ in Northern Africa (1). From a clinical point of view, three subtypes of BL have been described. One BL subtype occurs as an endemic disease in Africa, where it is associated with EBV infection in almost $100 \%$ of the cases. BL also occurs as sporadic cases throughout the world, including Romania. A third variant of BL is associated with acquired immunodeficiency syndrome. The three subtypes of BL occur at different ages, in different body sites, but share the same histological and cytological features (2). Most of the cases present with translocations of the MYC gene at band $8 \mathrm{q} 24$ to the $\mathrm{IgH}$ region, $14 \mathrm{q} 32$.

The $2008 \mathrm{WHO}$ classification proposes a new category of B cell lymphoma with intermediate features between diffuse large B cell lymphoma and $\mathrm{BL}$, including double hit or triple hit lymphomas, associating MYC rearrangements with BCL2 and/or BCL6 rearrangements (1).
Since BL is a very aggressive neoplasm, treated with high doses of chemotherapy, it requires an accurate diagnosis. One of the most challenging questions for the hematopathologist is the differential diagnosis between BL, DLBCL, and B-cell lymphoma, unclassifiable, with features intermediate between DLBCL and BL.

\section{Methods}

Twenty-two cases, previously diagnosed as $\mathrm{BL}$, were reviewed on histological and immunohistochemical basis, using antibodies against CD20 (L26 clone, dilution 1:100, Novocastra), CD10 (56C6 clone, dilution 1:100, Novocastra), bc16 (LN22 clone, dilution 1:100, Novocastra), bcl-2 (124 clone, dilution 1:50, DAKO), Ki 67 (MIB clone, dilution 1:75, DAKO), and Tdt (SEN 28 clone, dilution 1:100, Novocastra).

Immunohistochemistry was performed using an indirect bistadial technique performed with a polymer based detection system (EnVision+ Dual LinkSystem-HRP, Dako, Carpinteria, CA) according to the manufacturer's instructions.

FISH was performed on formalin fixed paraffin embedded material. For MYC rearrangement we used Vysis (Abbott) Probes, LSI IGH/MYC/CEP 8Tri-color Dual Fusion FISH Probe Kit.

Briefly: two 4-5 $\mu \mathrm{m}$ slides have been prepared for each specimen. The deparaffinized specimen were kept in $\mathrm{HCl} 0.2 \mathrm{~N}$ for 20 minutes at ambient temperature, washed with water and in 
kept pretreatment buffer between 8 seconds and $30 \mathrm{~min}$. Proteinase $\mathrm{K}$ digestion for $6 \mathrm{~min}$ at $37^{\circ} \mathrm{C}$ facilitates the access of the probe to the DNA target. Dehydration in EtOH 70\%, 85\% and 100\% solution, 1 minute in each, is followed by denaturation and hybridization. The labeled probes are applied on each tissue section than covered with a coverslip, and sealed with rubber cement. The samples are co-denatured with probes for $5 \mathrm{~min}$ at $72^{\circ} \mathrm{C}$ on a $\mathrm{HYB}$ denaturation / hybridization system. The hybridization lasts $14-18 \mathrm{~h}$ at $37^{\circ} \mathrm{C}$. The next day, hybridized slides are washed in $2 \mathrm{X}$ $\mathrm{SSC} / 0.3 \%$ at $73^{\circ} \mathrm{C}$; the coverslips are removed and the slides are counterstained with 40-6-Diamidino-2-phenylindole (DAPI). The slides may be stored at $-20^{\circ} \mathrm{C}$, for a long period of time.

The MYC rearrangement is indicated by the presence of 2 fusion signals (green/red) one red, one green and 2 aqua. The absence of myc translocation is indicated by the presence of 2 red, 2 green and 2 aqua signals.

The slides were examined on a Nikon epi-fluorescence microscope and the pictures were captured using Axio Imager Z1 Zeiss Microscope (Carl Zeiss, Germany) equipped with CCD camera, appropriate filters and dedicated software (Isis, MetaSystems, Germany).

\section{Results}

The 22 cases included in this study were typical Burkitt lymphomas: monomorphous medium sized cell proliferations with "starry sky pattern" due to the presence of frequent tingible body macrophages. Tumor cells have medium sized nuclei with several conspicuous nucleoli, and scant basophilic cytoplasm. Mitosis and apoptosis are frequent (Figure 1). The tumor cells were CD 20 positive, follicle center markers CD10 and blc6 positive, bcl2 and TdT negative and $\mathrm{Ki} 67$ proliferation index was between 97 and 100\% (Figures 2, 3).

From the $22 \mathrm{BL}$ cases tested for MYC, 17 were positive (Figure 4), 1 was negative and 4 were inconclusive. Positive cases had two fu- sion signals, one red and one green and two aqua signals. The negative case had two red, two green and two aqua signals.

\section{Discussion}

Burkitt lymphoma is one of the most aggressive lymphoproliferative diseases. Its diagnosis relies on morphology: medium sized cell proliferation, with diffuse growth pattern, conspicuous nucleoli, frequent mitosis, admixed with numerous tingible body macrophages. Tumor cells express CD20 and follicle center differentiation markers: CD 10 and bcl6, and are negative for bcl2. Ki67 proliferation index is about 100\%.

Most of the cases are characterized by translocations involving the MYC gene, diagnosed by FISH. MYC gene is located on chromosome 8 and encodes a transcription factor implicated in regulation of about $15 \%$ of the genes involved in the cellular cycle. MYC gene alterations are usually followed by constitutional activation of the transcription factor and gene upregulation, and confer an important growth advantage to tumor cells (3). The most frequent translocation in $\mathrm{BL}$ is between c-Myc gene, located on 8q24, and the gene for immunoglobulin heavy chain $\operatorname{IgH}$ on $14 \mathrm{q} 32$, or, less frequently with lambda gene on 22q11 and kappa gene on $2 \mathrm{p} 12$. About $10 \%$ of the cases do not have a cMyc translocation detectable by FISH. Other possible genetic and epigenetic abnormalities involve p16INK4a, p53 and BCL6 genes $(4,5) \mathrm{Be}-$ sides gene rearrangements, there may be mutations or somatic hypermutations characteristic for germinal center B cells $(4,6,7)$.

In cases lacking MYC translocation, miRNA deregulation may be responsible for elevated levels of c-Myc expression (8-10).

The 2008 WHO classification proposes a new category of Unclassifiable B Cell Lymphomas, with intermediate aspects between BL and DLBCL, including cases with coexistent MYC and bcl2 and/or BCL6 rearrangements (double-hit or triple-hit lymphomas) $(1,11)$. This 


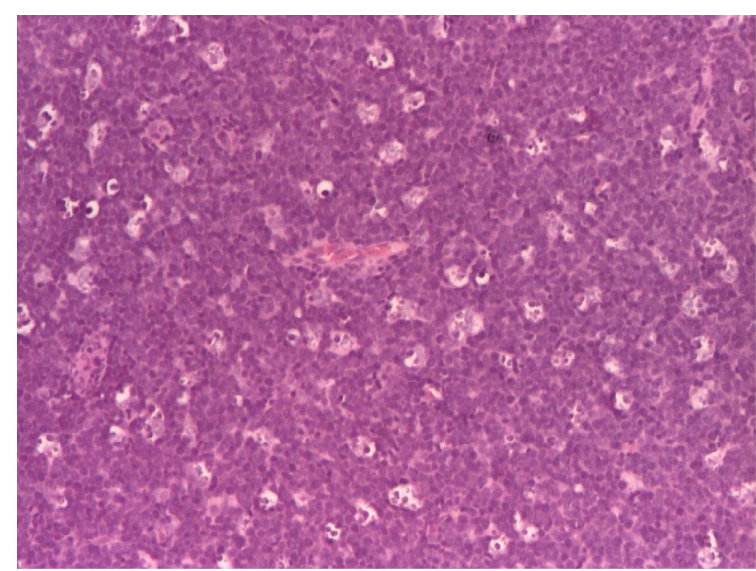

Figure 1. Burkitt lymphoma. Medium-sized cell proliferation with starry sky pattern and frequent mitoses, HE stain, 10X

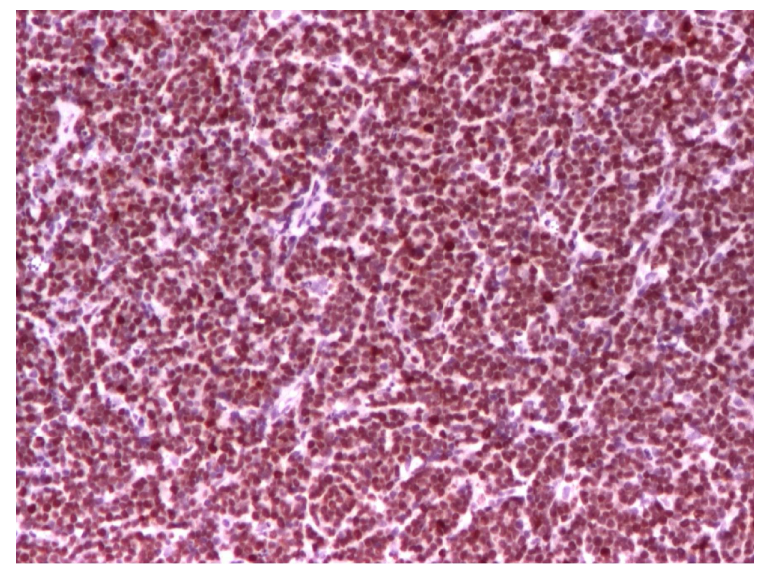

Figure 3. Ki 67 proliferation index over 97\%, 10X

type of lymphoma is an aggressive neoplasm usually characterized by the presence of a germinal center phenotype (L26, CD10, bc16 positive), and high proliferation rates. However these lymphomas have an intermediate morphology between BL and DLBCL or atypical immunophenotype: bcl 2 is frequently positive or Ki 67 proliferation index is less than $95 \%$. From a clinical point of view, this category of lymphomas is characterized by more frequent bone marrow and central nervous system involvement and higher

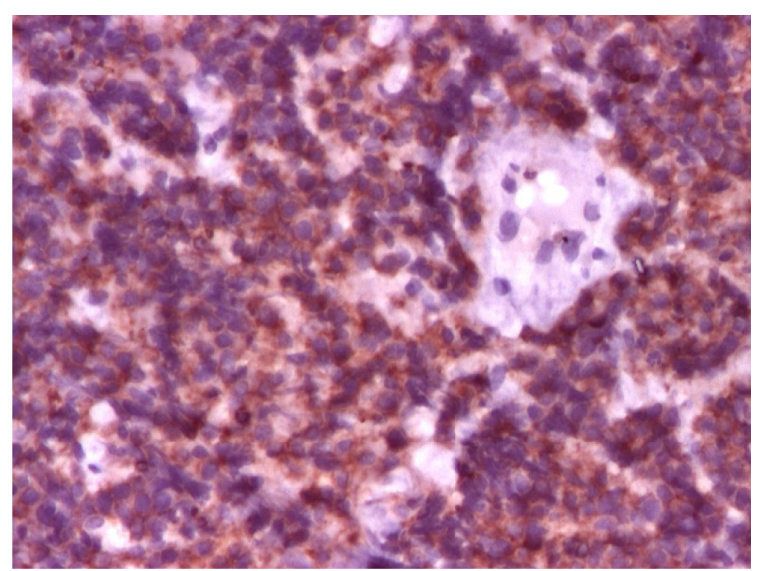

Figure 2. Burkitt lymphoma. CD 10 diffusely positive, 20X

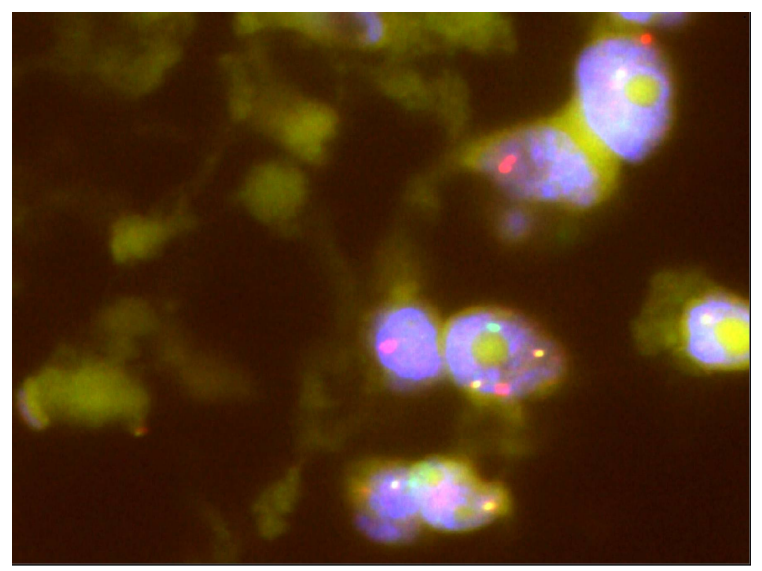

Figure 4. Positive case for FISH testing, showing one tumor cell with two fusion signals green-red, one green signal and one red signal

LDH levels at presentation, when compared with $\mathrm{BL}$ or DLBCL cases. The overall survival is inferior to that of BL or DLBCL $(12,13)$.

One of the most challenging issues in hematopathology is the differential diagnosis between BL, DLBCL and B-cell lymphoma, unclassifiable, with features intermediate between DLBCL and BL. This decision has important therapeutic implications, since the treatment of BL is very aggressive, but its prognosis after therapy is favorable. 
FISH testing for MYC is a reliable method for confirmation of Burkitt lymphoma diagnosis, made on morphological and immunohistochemical basis (14). Some algorithms of differential diagnosis between BL, DLBCL and B-cell lymphoma, unclassifiable, with features intermediate between DLBCL and BL have been proposed, stipulating the evaluation of MYC and BCL2 rearrangements in cases that are clinically suggestive of double hit lymphomas (with early bone marrow and CNS involvement or high LDH levels) or atypical phenotype $(13,15)$.

The purpose of our study, part of the PERSOTHER project, was the implementation of new ancillary techniques in routine pathological diagnostic practice in Romania. We performed FISH testing for MYC on a series of 22 cases. The tissue samples were formalin fixed and paraffin embedded. This first series of results allowed us to improve some technical aspects, and to train in performing the FISH testing on paraffin embedded tissue, and in interpreting the results. 17 of our cases were positive, 1 was negative and 4 were inconclusive, due mainly to the inadequacy of the paraffin embedded tissue samples. FISH for MYC on paraffin embedded tissue has several advantages: testing can be performed on archived material, and on all types of tissue samples. Together with morphology, immunohistochemistry and BCL2 FISH evaluation, it allows us to make a differential diagnosis between BL, B-cell lymphoma, unclassifiable, with features intermediate between DLBCL and BL and DLBCL. The disadvantages of this technique are due to tissue processing and paraffin block preparation, and to the difficulties related to counting an interpretation of FISH on paraffin embedded material.

Our study highlights the importance of FISH in BL diagnosis and identifies some technical difficulties of this method. Although the study has limitations related to the number of cases, it is a first step in the implementation of FISH in routine hematological pathology in our country and it opens the way for future research concerning gray-zone lymphomas.
Acknowledgements. We thank Dr. Aurora Arghir for her help and technical support in picture capture. The research was supported by the project PERSOTHER POS CCE O2.1.2. cod SMIS-CSNR 549/12024.

\author{
Abbreviations \\ BL - Burkitt lymphoma \\ DAPI - 40-6-Diamidino-2-phenylindole \\ DLBCL - diffuse large B-cell lymphoma \\ Epstein-Barr Virus (EBV) - Epstein-Barr Virus \\ FISH - fluorescent in situ hybridization \\ MiRNA - micro-RNA \\ WHO - World Health Organization.
}

\section{References}

1. Leoncini L, Raphael M, Stein H, Harris NL, Jaffe ES, Kluin PM. Burkitt Lymphoma. Swerdlow SH, Campo E, Harris NL, Jaffe ES, Pileri SA, Stein H, et al. World Health Organisation Classification of Tumours of Haematopoietic and Lymphoid Tissues. 4th ed. IARC Lyon. 2008: 262-264.

2. Wright DH, Leong AS-Y, Addis JB. Burkitt Lymphoma/Leukemia. Joanna Koster. Diagnostic lymph node pathology. Hodder Arnold. G London. 2006: 86-90

3. Dang CV, O'Donnell KA, Zeller KI, Nguyen T, Osthus RC, Li F. The c-Myc target gene network. Semin Cancer Biol. 2006 Aug;16(4):253-64.

4. Delsol G. Molecular abnormalities in lymphomas. Bull Cancer. 2010 Nov;97(11):1347-64.

5. Roberti A, Rizzolio F, Lucchetti C, de Leval L, Giordano A, Ubiquitin-mediated protein degradation and methylation-induced gene silencing cooperate in the inactivation of the INK4/ARF locus in Burkitt lymphoma cell lines. Cell Cycle. 2011 Jan 1;10(1):127-34.

6. Reichard KK, Hall BK, Corn A, Foucar MK, Hozier J. Automated analysis of fluorescence in situ hybridization on fixed, paraffin-embedded whole tissue sections in Bcell lymphoma Mod Pathol. 2006 Aug;19(8):1027-33.

7. Love C, Sun Z, Jima D, Li G, Zhang J, Miles R, et al. The genetic landscape of mutations in Burkitt lymphoma. Nat Genet. 2012 Dec;44(12):1321-5.

8. Onnis A, De Falco G, Antonicelli G, Onorati M, Bellan $\mathrm{C}$, Sherman O, et al Alteration of microRNAs regulated by c-Myc in Burkitt lymphoma. PLoS One. 2010 Sep 24;5(9).

9. Leucci E, Cocco M, Onnis A, De Falco G, van Cleef $\mathrm{P}$, Bellan C, et al. MYC translocation-negative classical Burkitt lymphoma cases: an alternative pathogenetic mechanism involving miRNA J Pathol. 2008 Dec;216(4):440-50. 
10. Onnis A, Navari M, Antonicelli G, Morettini F, Mannucci S, De Falco G, et al. Epstein-Barr nuclear antigen 1 induces expression of the cellular microRNA hsa-miR-127 and impairing B-cell differentiation in EBV-infected memory B cells. New insights into the pathogenesis of Burkitt lymphoma. Blood Cancer J. 2012 Aug 31;2:e84.

11. Dobrea C, Al Salamat H, Lupu AR. Diffuse large Bcell lymphoma - a new look and old prognostic factors. Rev Rom Med Lab, 2012 Dec 20(4): 307-315.

12. Snuderl M, Kolman OK, Chen Y-B, Hsu JJ, Ackerman AM, Dal Cin P, et al. B-cell lymphomas with concurrent IGH-BCL2 and MYC rearrangements are aggressive neoplasms with clinical and pathologic features distinct from Burkitt lymphoma and diffuse large B-cell lym- phoma. Am J Surg Pathol. 2010 Mar;34(3):327-40.

13. Naresh KN, Ibrahim HA, Lazzi S, Rince P, Onorati M, Ambrosio MR, et al. Diagnosis of Burkitt lymphoma using an algorithmic approach - applicable in both resource-poor and resource-rich countries. Br J Haematol. 2011 Jul 1. 154:770-776.

14. Aukema SM, Siebert R, Schuuring E, van Imhoff GW, Kluin-Nelemans HC, Boerma EJ, et al. Double-hit Bcell lymphomas. Blood. 2011 Feb 24;117(8):2319-31.

15. Campo E, Swerdlow SH, Harris NL, Pileri S, Stein H, Jaffe ES. The 2008 WHO classification of lymphoid neoplasms and beyond: evolving concepts and practical applications. Blood. 2011 May 12;117(19):5019-32. 